\title{
The Changing Face of Employment Relations over the Last 50 Years
}

In this special issue of Employee Relations an unrivalled line-up of authors provide a fascinating reflective historical commentary on the changes and continuities within employment relations in Britain over the last fifty years, as well as consider future challenges and prospects. The special issue emerges from the $50^{\text {th }}$ anniversary conference of the Manchester Industrial Society which was held in November 2014 and attended by over 200 industrial relations academics, trade union officers, TUC officials, HR professionals from the Chartered Institute for Personal and Development (CIPD), officials from the Advisory, Conciliation and Arbitration Service (Acas), labour lawyers from the Industrial Law Society, and postgraduate employment relations/HRM students. The conference provided an important testimony to the continuing theoretical and practical contemporary relevance of the field of employment relations, and in the process celebrated the Manchester Industrial Relations Society's distinctive contribution since 1964. The event was sponsored and financially supported by the CIPD, Acas, TUC, British Universities Industrial Relations Association (BUIRA), Salford Business School, Fairness at Work Research Centre at Manchester Business School, and Manchester Metropolitan University Business School. Virtually all of the conference presentations were subsequently further developed and written up for this special issue of Employee Relations, alongside some other individual contributions, that collectively attempt to reflect on past achievements, changing landscapes and processes, emerging issues and problems, and future trajectories about the world of employment relations. In sum, this is likely to be a seminal issue of the journal that will be an important teaching and research resource for many years to come.

The first two articles explore the theme of the changing patterns of work and employment relations since the mid-1960s. To begin with, Jill Rubery identifies the so-called 'Four Fs of Employment Change': 'Feminisation' of labour, especially part-time work and the attendant gender pay gap; 'Flexibility' from standard to flexible and transient employment; 'Fragmentation' of work across organisational boundaries and organisational types;' and 'Financialisation' involving increased market de-regulation and global neoliberalism shaping the conduct of employment relations. The article pinpoints the way these four trends, despite different origins and pace of development, have created a world in which employees increasingly face an insecure, less transparent and more ambiguous form of employment.

Paul Marginson then examines the remarkable decline of collectivism as the main way of regulating employment relations (ER), with reference to collective representation and organisation, collective bargaining coverage and structure, the scope (agenda) of collective bargaining, and joint consultation arrangements. He highlights three underlying processes: 'marketisation' (with a shift from an industrial/occupational frame to an enterprise frame in collective ER); the rise of 'micro-corporatism' (with an increased focus on common interests of collective actors within an enterprise frame); and the changing nature of voluntarism (with attempts at a legally-induced or legislatively-prompted voluntarism 
leading to meagre outcomes, and 'asymmetric' voluntarism with management decisions increasingly predominant in determining 'fact' and trajectory of collective ER).

The next three articles provide different practitioners' perspectives from the respective vantage points of the CIPD, Acas and the TUC. Mike Emmott (advisor to the CIPD) refocuses analysis away from the field of 'industrial relations' to 'employee relations' (ER), including issues related to managing the employment human resources, conflict management, employee engagement, employee voice, and the role of the CIPD in supporting good practice in people management. He probes the extent to which alternative dispute resolution could be integrated into strategic conflict management, and advocates the need to bring key 'social partners' together to form a hub for advising government on workplace issues and for a government-supported, sector-based and workplace-focused campaigns on productivity, performance and good work.

Gill Dix and Brendan Barber provide an overview of some of the most significant developments that have affected Acas' role across a forty year period, namely the task of promoting good individual and collective relationships in the workplace, and offering effective third-party dispute resolution; in particular the authors focus on two areas that have dominated policy concerns - workplace disputes and the question of employment regulation.

Paul Nowak then provides an overview of the key trends within the trade union movement over the past 50 years, suggesting there has been three key phases between 1964 and 2014: the first phase, from 1964 to the late 1970s, was a period of growth and expansion; the second phase, from the early 1980s to the mid ' 90 s, was a period of 'survival' with unions having to respond to the end of the post-war consensus, industrial change, the rise of de-regulation and Thatcherism; and the third phase, from the mid ' 90 s to the present day, was one of 'resilience if not resurgence'. It is suggested unions could learn three key lessons from the half century after 1964: organising is crucial; unions can only grow if they reach out to new groups of workers; and unions need to be confident enough not to be confined within what former TUC general secretary Walter Citrine described as the 'traditional walls of trade union policy'.

The following two articles shift the focus of attention towards respectively state regulation of employment relations and the issue of equality and diversity. Miguel Martinez Lucio argues that increasingly progressive state interventions on a range of subjects over the last 40 years, such as equality, health and safety, and others, have coincided with a greater commercialisation of the state and greater fragmentation, with a growing set of tensions and breakdown in consensus over workers' rights. He argues that with agencies of the state and other state bodies entrusted with the development of a more socially-driven view of employment relations becoming increasingly undermined and weakened, the political context of employment relations has become more fractured and unable to sustain a coherent longer term view.

In examining the changing face of employment relations with reference to equality and diversity, Sian Moore and Stephanie Tailby look at what has happened to both the notion and the reality of equal pay over the past 50 years and the tension between 
voluntary and legal responses to discrimination as 'vehicles for equality'. In the process, they consider the potential for collective bargaining to be harnessed to equality at work, and in considering the shifting relationship between liberal and radical models of equality also probe the limited extent to which legal measures, such as the National Minimum Wage from 1999 and the Equality Act 2010, have provided solutions to closing pay gaps and wider social inequalities.

The collective expression of conflict within the employment relationship over the last 50 years, notably strike activity, is then examined in two different but complimentary articles. John Kelly concentrates attention on changing trends and patterns of collective action (notably the way the decline of union density, organisational capacity and bargaining coverage has shrunk the opportunity structures through which to put leverage on employers), but argues declining conflict at work does not entail a decline in conflict about work. He identifies varieties of collective action (coalition building between unions and civil society, political lobbying of key decision makers at different levels, online petitions and social media, occupations of public spaces, and general strikes and demonstrations) and considers the links between strike and protest waves in Europe and the restructuring of class representation in the political system.

Dave Lyddon further explores four interrelated features that have dominated the past 50 years of strikes: their contours (there are now far fewer of them); their changing locus (from coalmining and manufacturing to the public services and privatised utilities); relationship between officials and unofficial strikes (the latter are no longer the dominant form); and the return of the labour injunction (whereas legislation and the courts tended not to interfere with strikes, the opposite is now the case). Although the number of strikes and days lost remain at historically low levels, it is argued recent series of national public service stoppages have significantly increased the number of strikers (especially women) from its nadir in the 1990s and, notwithstanding anticipated government legislation further curtailing industrial action, there is likely to be a continuing durability, adaptability and inevitability of the strike weapon.

The final article by Roger Seifert on the British industrial relations tradition after Donovan provides a forthright and provocative Marxist critique of the perceived highly negative role leading IR academics of the 1960s (such as Hugh Clegg, Bill McCarthy, Allan Flanders, Alan Fox and George Bain) played in compromising a critical analysis of the antagonistic dynamic of the employment relationship, something which it is argued has been subsequently accentuated with the academic study of HRM in Business Schools.

In sum this special issue of Employee Relations provides a distinctive contribution to the analysis of the changing nature of work and employment relations in the UK over the last 50 years, and its potential future challenges and opportunities, as well as underlining the theoretical and practical contemporary relevance of the field of industrial relations broadly defined. 